\title{
Building a firm foundation: ACRL leadership, 1939-1989
}

\author{
By Edward G. Holley \\ School of Information and Library Science \\ University of North Carolina at Chapel Hill
}

\section{Presented at the luncheon in honor of academic leaders held at the ACRL Fifth National Conference in Cincinnati, April 6, 1989.}

\begin{abstract}
$\mathbf{W}$ 1946 , for the first time since that perennial gadfly, John Cotton Dana, had led the special librarians out of the Association in 1909, the ALA executive director and Executive Board experienced the greatest trauma they ever had. Those quarrelsome academic librarians had been difficult enough in the twenties and thirties, when they plotted a reorganization leading to ALA's first semi-autonomous division. They had claimed that ALA ignored academic librarians (true enough, to be sure). They wanted more attention to their special needs and better support for their programs. And they were determined to attain their objectives.

Under the leadership of Charles Harvey Brown (1875-1960), a consummate politician if there ever was one, ACRL was born in 1938. Our official journal, College and Research Libraries, was launched in December 1939 under the editorship of the vigorous and articulate A. Frederick Kuhlman. For the first eight years, to use the current jargon, ACRL "didn't get no respect." And so, in 1946, the battle was joined. Was ACRL to separate from ALA and become an independent organization or was ACRL to remain within the ALA with more autonomy and a full-time executive secretary?
\end{abstract}

After a highly emotional meeting at the ALA Conference in Buffalo in 1946, led by that aggressive ACRL president, Blanche Prichard McCrum, the struggle was over. The ALA Executive Board capitulated, gave ACRL an executive secretary in 1947, and ACRL moved farther down the road toward autonomy within ALA.

The ACRL rebellion has been recounted elsewhere but perhaps no one has yet told the complete story of the behind-the-scenes maneuvering, the incendiary letters that passed between the opposing forces, and the resistance of persons like Carl Milam, ALA executive secretary, and ALA Executive Board members Ralph Ulveling, and Mary Utopia ("Topey") Rothrock. On the ACRL side the leaders included McCrum, Brown, Ralph Ellsworth, and, behind the scenes, Kuhlman. Incoming 1946-1947 ACRL President E. W. McDiarmid, who would, in 1948-1949, become ALA's youngest president in its history, seemed to be a moderating force, with an assist from that Machiavellian change agent, Charlie Brown, who couldn't bring himself, in the words of Ralph Ellsworth, "to break up the good old ALA."

Parenthetically, Brown, who had the most to do with ACRL's founding, was never president. How- 
ever, he saw to it that the first president, Frank K. Walter, was someone he trusted, to lead the college librarians in the right way.

What a decade that first one was! The leadership included Frank K. Walter at Minnesota and Phineas L. Windsor at Illinois. Up and coming younger librarians included Robert B. Downs and Donald Coney, who would argue with each other over most of their careers about the merits or demerits of faculty status for librarians.

Three women were president: Mabel L. Conat, head of reference at the Detroit Public Library (remember that ACRL was "College and Reference Librarians" until 1956), followed two years later by another reference librarian, Winifred Ver Nooy, and then McCrum.

Not yet mentioned is Charles B. Shaw, of the famous Shaw List of Books for College Libraries, predecessor to our currently highly respected BCL3.

Completing the decade was William $\mathrm{H}$. Carlson, who was a member of the ALA Committee on postwar planning. At the time of his presidency Carlson was director of libraries for the Oregon State System of Higher Education. He had also chaired the College and University Postwar Planning Committee which in 1946 had produced College and University Libraries and Librarianship, a major assessment of and plan for the future of academic libraries.

That first decade also saw the appointment of ACRL's first executive secretary, N. Orwin Rush, 1947. Rush established a pattern that has become familiar in ACRL: executive secretaries have been persons who assumed the position, did their duty, and moved on to other positions.

After two years, Rush was succeeded by young Arthur T. Hamlin, described as "fresh from the University of Pennsylvania." In Hamlin's sevenyear tenure, he oversaw the birth of the ACRL Monograph series, including its first hardcover book, Charlie Brown's Scientific Serials, 1956.

What of the next four decades? Under one of its periodic, but strife-producing, organizational studies, ALA established new divisions, including the Reference Services Division. With the departure of the reference librarians, ACRL was renamed the Association of College and Research Libraries (following, incidentally, the name of its journal), and thus it remains.

The fifties saw continuation of higher education's enrollment expansion which led Donald Coney to write a perceptive article in $C \triangleleft R L$, "Where Did You Go? To the Library. What Did You Get? Nothing." The growth of college and university libraries followed higher education's lead: books, buildings, staffs, and staff salaries began their own long-awaited expansion. Michigan followed Harvard's lead and opened a separate undergraduate library in 1958. That particular year promised even more explosive growth of libraries as the country reacted to Sputnik with a National De- fense Education Act which included support for acquiring library materials from abroad.

Higher education accrediting associations strengthened their standards, as did ACRL, whose 1959 college library standards would have a tremendous impact in the sixties when many entirely new college and university campuses came into existence.

Among the respected ACRL leaders of this period were names familiar to many a library school student of my generation; college librarians like Wyllis E. Wright of Williams College, Eileen Thornton of Oberlin, Wyman W. Parker of Wesleyan. The controversial Ralph Ellsworth, the only person to be elected ACRL president twice, again became ACRL president in 1961. Also Guy R. Lyle, whose textbook on college library administration went through four editions. And Robert Vosper, whose directorships at Kansas and UCLA made their libraries into national research collections. Vosper, along with Downs, McDiarmid, Ben Powell, and Russell Shank, was one of the five ACRL presidents who also served as presidents of ALA. Not to be overlooked is Edmond Low, the indefatigable leader in federal legislative and copyright battles.

As we look at the list of leaders over this period and the succeeding two decades, we cannot help being impressed with how fortunate ACRL has been in its leadership. Presidents and executive secretaries led the Association through tumultuous times: the golden age of federal support, especially during President Lyndon Johnson's Great Society Programs; the retrenchment of the seventies; the blahs and financial pressures of the eighties.

Let us confess that on a few occasions leadership was not always what one might have wished. At one period an executive secretary lamented to me that the current president didn't wish to be bothered making tough decisions. The individual said, "I have to deal with these problems all the time at

\section{Got a policy?}

The Reference Collection Development and Evaluation Committee of the Reference and Adult Services Division's Collection Development and Evaluation Section is initiating a project to gather the reference collection development policies currently in place in all types of libraries. The committee hopes to publish the collection of policies after the documents are received and categorized.

All types of libraries-academic, public, school, and special - having collection development policies referring specifically to their reference collection or including a section on the reference collection are urged to forward the policies to: Jane Kleiner, Chair, CODES Reference CD\&E Committee, Louisiana State University Libraries, Baton Rouge, LA 70803. 
home. I don't want to come to the ALA conference and repeat that experience." The executive secretary expostulated that this was an irresponsible attitude and if an individual did not wish to deal with ACRL problems, that person should not seek elective office. I suspect that a number of executive secretaries had similar problems on occasion. However, on the whole, the presidents have served us well. The foundation they laid is one which should give us both satisfaction and pride.

One of the disappointments when one looks backward is the lack of women and minorities in significant positions, except in recent years.

Oberlin librarian Eileen Thornton (who is with us today), was the only woman elected president in the fifties, while the sixties saw the presidencies of Kitty Stokes, from Western Michigan, and Helen Margaret Brown, from Wellesley. By the seventies the situation was changing, with the appearance of Anne Edmonds, Louise Giles, and Connie Dunlap. The eighties, of course, have seen six distinguished women presidents in succession.

Women have also dominated the executive secretary/director position since Beverly Lynch's selection in 1972. Dr. Lynch, soon to become dean of the UCLA Graduate School of Library and Information Science, is another ACRL leader who became ALA president.

Joseph Reason became the first AfricanAmerican to become president in 1971-1972. Reason had also served as interim executive secretary a decade earlier, 1962-1963. The only other AfricanAmerican president was Louise Giles, whose tragic death in the middle of her presidential term cut short a promising career.

As already mentioned, behind the scenes were the executive secretaries/directors. These able persons, sometimes for short periods, sometimes for longer periods, kept the Association on track during the turmoil of the late sixties and early seventies. And under the leadership of Beverly Lynch, Julie Virgo, and JoAn Segal they saw the Association become in fact, if not in theory, the truly autonomous ALA unit for which the ACRL founders had fought.

From the beginning university librarians have been the most numerous among ACRL presidents and executive secretaries. Overall, 35 of the 50 presidents have come from university libraries, perhaps not surprising since about fifty percent of the membership also comes from university libraries.

From Frank K. Walter in 1938-1939 to Joseph W. Boissé in 1988-1989, they have given dedicated service to our Association. This has been true despite the assertion that the Association of Research Libraries has drained ACRL of research library leadership. Of course, not all university directors have come from ARL institutions, but a significant number have, including a number of the presidents in the last decade.
Eight of our fifty presidents have been college librarians, while one came from a community college library, two each from public libraries and other agencies, and two from library schools. Most of the ACRL presidents have been directors of libraries, again not surprising.

For oldtimers like me, who have both participated in and observed our Association of College and Research Libraries mature, the accomplishments of the last two decades provide a firm foundation on which to build for our next century. As I indicated in the January $C \& R L$, the facts are clear. Thanks to a dedicated membership and strong presidential/executive director leadership, ACRL on its fiftieth anniversary is far and away the largest, most effective, and most prosperous of the ALA divisions. Among all the library associations of the world, ACRL ranks fifth in membership.

Our Association has led the way in ALA divisional national conferences, in continuing education, and in noteworthy professional and scholarly publications. Our college library standards, and other standards and guidelines, are recognized unofficially, if not officially, as the objectives for academic libraries to attain. Our journals, Choice, College \& Research Libraries, Rare Books \& Manuscripts Librarianship, and College \& Research Libraries News, are pre-eminent in their field. We owe a debt of gratitude to all those who have made contributions, whether large or small, to such an outstanding Association record.

As I studied ACRL's past leadership, I came across William $H$. Carlson's remarkable article, "Preparation for Progress," written at the beginning of his presidency in 1947. That year was a time of high hopes and some apprehension. ACRL's first executive secretary would soon take office and set the stage for a new relationship of the division with ALA. Membership, recruitment, educational preparation of librarians, and financial support for ACRL's expanded activities were very much on Carlson's mind, even as they are today. In speaking or the importance of that time, Carlson wrote: "All of us must surely approach the work of the forthcoming years with a sense of unusual opportunity. What we do in these first years...may determine the pattern of our development and the effectiveness of our work for a long period of years. The next very few years will determine whether we are to shape and sharpen, whether we can shape and sharpen our association into an instrument equal to the times. We must succeed. With the help, support, and active work of every college, university, and reference librarian we will succeed." College \& Research Libraries 8 (July 1947): 202.

Like Carlson, at the beginning of our next one hundred years, we too "must surely approach the work of the forthcoming years with a sense of unusual opportunity." Our look at the past should give courage to our future leaders as they prepare 
ACRL for the twenty-first century. Our predecessors built a firm foundation. Their accomplishments, in good times and bad, served the academic library profession well. Appropriately, we salute those leaders, and express our special thanks to those who are with us today. And let us, as we leave
Cincinnati, also "approach the forthcoming years with a sense of unusual opportunity." "With the help, support, and active work" of every ACRL member, we, too, will succeed.

Thank you.

\title{
The University of Florida's
}

\section{moving experience}

\author{
By Anita L. Battiste, Denise M. Beaubien, Carol A. Drum, \\ Beverly L. Pope, and Alice L. Primack \\ University of Florida
}

\section{Consolidating branches into a central science library.}

\begin{abstract}
I n February 1987 the Marston Science Library at the University of Florida first opened its doors to the public. At that time, four branch libraries were closed and the agricultural, biological, physical and earth sciences, and mathematics libraries were consolidated in the new location. This article discusses the phases and events that led to the opening of the new library, from choosing an architect to the final integration of collections and staff in the new facility.
\end{abstract}

\section{Background}

The idea of a centralized science library at the University of Florida was conceived more than twenty years ago, but it did not have widespread acceptance among the science faculty, university administration, or state legislature at that time. There were four departmental branch libraries on campus: agriculture, chemistry, engineering, and physics/astronomy. Other science disciplines (except medicine) were served by the main library.
By the middle to late 1970 s, the branch locations as well as the main library were becoming seriously overcrowded. Limited budgets had necessitated the cancellation of most duplicate journal subscriptions, forcing some science researchers to use up to five different libraries on campus in order to do their research. The theft rate had increased dramatically in libraries with 24-hour key access and/ or limited security. To secure these libraries would have meant the elimination of faculty and graduate student key access and expensive alterations to the buildings. Gradually, support for a central science library grew among the faculty and administrators. After a number of years of jockeying for position on the state's building priority list, the library was funded in the early 1980 s.

\section{Designing and refining the building}

Library committees were formed to provide input on programs and issues that would directly affect the design of the library: circulation/reserves, automation, interlibrary loan, documents, etc. 